\title{
Refusing to Kill My Darlings
}

\author{
Lisa Lebduska
}

Lisa Lebduska directs the College Writing Program at Wheaton College in Massachusetts, where she also teaches courses in expository writing. Her work has appeared in or is forthcoming in such journals as College Composition and Communication; Writing on the Edge; Present Tense, Harlot and The Forge, among others. She lives in Salem, Connecticut, near Devil's Hopyard, where she and her husband enjoy hiking with other people's pets.

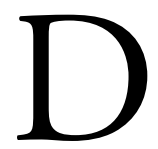

uring my first graduate seminar, ever, Professor Smith advises, "Kill all your darlings." He leans on the squeaking conference table, making it sway, just as it does whenever someone replaces the matchbook shoved under one of its legs for balance, and we all sway with it, watching him, the captain of our rollicking ship. His gravitas withstands the rumpled weariness of his plaid shirt, the spattered lenses of his aviator glasses. He has published fiction and criticism and a slender volume about revision, chaired English departments in two different states, and talks about Robert Frost and Ezra Pound as soulmates. Before I graduate, he will reach for my hand while I am eating a turkey sandwich, as if to comfort me, but I see the leer in his eyes and pull back, knowing he is married and that I have a boyfriend. Later, I will hate myself for wondering if I would have left my hand exactly where it was had his nose been a little less smashed, had his cheeks been chiseled and high instead of pockmarked and sagged, his eyes bright with life and not rheumy with regret.

But he is a deep-voiced, tall White man, just like all the other authorities in my life: my father, my older brother, every school principal and politician, including every president, I have ever seen. And I am White, too. I want to join the club completely, to press my advantage. So I drink down his advice without question, the price of admission to Valhalla, pledging never to become too attached to any wording or idea that stands between my readers and me, no matter how much I love it, no matter how hard I have worked on it. If it has to go, it has to go. What I care about does not matter if it doesn't appeal to the audience I assume are "general readers," unable to see Professor Smith, the White male reader whispering, an insistent ghoul, over my shoulder.

Alone at my desk, I strike: The that accompanied a woman narrator as she boarded a Greyhound. I hunt sentimentality and glib asides, hacking away at marble and lard, searching for muscle. Words, phrases, and paragraphs lie mutilated and abandoned, and a rush of pride fills me. Once I kill a darling, I move on, never asking "What did I mean?," which I do not realize holds the hand of a "Who am I?" I do not yet see that when a writer changes their answer to either one of these questions, it pulls the other along with it. It will take me decades to understand that these two questions sit side by side, along for the same ride, with an undying loyalty to one another. I will 
mean what someone else wants me to mean, and in doing so, I will become who they say I am and who I should be. At that moment, the ability to annihilate my darlings without remorse simply emboldens me when courage is in shorter supply than money. My family loves me despite their view of graduate degrees in English as pointless self-indulgence. At their jobs in healthcare, they risk contagion, mop blood. I read stories, type words. I want to offer my ruthless self-editing as proof of my tough pragmatism. I murder to create the tidy surface of a barely frozen pond that crackles prettily as long as I don't try to cross it with anything heavy. I avoid discussions that might smash the chilled smoothness and plunge me into dark, frigid waters. Killing my darlings allows me to continue, so when I walk into my first first-year writing classroom (known then by the gendered title Freshman Composition), it makes sense that I channel Professor Smith.

"William Faulkner said, 'Kill your darlings. They are only holding you back."”

I sound so cool to myself. I fantasize that the students see me as the brash, hip instructor who will lead them to fresh, dangerous heights of literate accomplishment. From the safety of my sangfroid seat I can also preempt complaints about grades, which I worry about, having heard stories from new instructors struggling to confer anything but As. Seasoned faculty talk about "managing student expectations," meaning we must teach students not to expect high grades; I extend this advice to include embracing the principle of "kill your darlings." I will get them to accept, without question, what I advise them to eliminate. Faculty can be so masterful at this. I want to manage student expectations about the amount of revision required to improve their work so they are prepared for considerable work and sacrifice. I imagine that if students accept the "darlings" mantra, I can help them excise and chop with impunity and without objection. If they understand revision as an act of courage and honor, they will never complain about what I have said about their writing. I decide I am just there to help them clean up their prose and teach them to accept the brutality that is the revising process. That is my responsibility, I think. I never dream that is my privilege. My White privilege.

My privilege allows me to avoid thinking about what revising takes out of all writers. Or, more precisely, it especially allows me not to think about what revising takes out of writers who do not share my background, who are not me. I don't stop to think about how the comment contributes to the dehumanization and marginalization Black students endure as a result of their education in the United States from the time they are very young. Throughout their schooling, as researcher April Baker-Bell has documented, Black students perpetually negotiate their linguistic and racial identities, traversing multiple contexts that often threaten their sense of self-worth. Too often, Baker-Bell notes, Black students internalize their educational marginalization. A comment such as "kill your darlings" serves only to further marginalize students, as it says what they care most about (their "darlings") must die by their own hands if they wish to succeed.

All revision involves a certain level of savagery: something that seemed logical or pertinent or funny or beautiful at some point gets moved or altered or maimed or exiled. At its gentlest, most fecund, the act comes from within, guided by an inner editor or even an outside reader whose insight we value and trust. But the process nevertheless demands fortitude, strengthened by the confidence (perhaps even past knowledge) that we are creating, discovering, excavating towards a better result. When I decree "kill your darlings" to another writer-particularly to a novice writer-। am rendering myself insensate to the ferocity of revision and pretending my reading of a student work is context free. I am using context, but it is the context of my White life, drowning out the contexts of my students' lives. Such tone deafness ignores the sage advice of scholars such as Ira E. Murray and Adam Alvarez, who explain the importance of tending to identity in student development, which includes the need for "educators [to] deepen their knowledge of sociopolitical histories of their students' communities and the people who make up those communities" (17). "Kill your darlings" prevents students both from saying who they are and from growing into the fullness of their own humanity. By making their essays more suitable for "the academy," I am insisting that students make their essays palatable to a White academy.

Comments such as "kill your darlings" lurk within the writing assessment "ecology" that Asao Inoue describes, reproducing a "political, cultural, linguistic, and economic dominance for White people" (8). This restrictive ecology is a calcified network that does not expand to embrace or celebrate that which is not already present, that which does not fit into a preordained idea about acceptable expression. It rejects anything that does not help it reproduce itself. In order to "kill their darlings" based on my assessment, students suffocate parts of themselves, whether it is a word, phrase, or sentence; a claim or an image. Under the guise of rigor, "kill your darlings" burrows into the contemporary racism Baker-Bell, Tamara Butler and Lamar Johnson describe as "covertly etched within the American fabric [that has supplanted] black bodies hanging from trees and bearing the brunt of fire hoses" (117). Wielded over and over, handed down from generation of White professor to generation of White professor, the phrase becomes a cultural practice that normalizes White privilege. There are two problematic moves with "kill your darlings," then: one concerns what material we advise students to excise; the other involves the language of the message itself-everything that lies behind this violent aphorism of creative writing lore.

Writing instructors often take comfort in the restorative and affirming potential of writing, yet when they use the dismissive cliche "kill your darlings," they extinguish parts of student experience and identity. Regardless of intention, when White instructors adjure writers to "kill their darlings," they participate in a form of cultural violence known as "spirit murdering," a phrase writer Bettina 
L. Love, borrowing from legal scholar Patricia Williams, uses to explain the ways racialized trauma extends beyond physical violence to attack the psyche and psychological well-being of people of color. "Spirit murdering," Love explains, deprives students of color of the potential safety and sanctity of the classroom space. Even if they are not under physical attack, their psyches are under assault from messages telling them they are not right, not enough, not visible. This threat quakes the psychic house all writers must inhabit in order to write. Imagine knocking on the door of a room that will open itself to you only if you can transform yourself into someone else, if you can enter masked, as someone who is not completely and entirely you-an admission ticket with the highest of all possible costs. Without asking and really listening to what students are trying to say, instead insisting on my own ideas of what would create an ideal (read: White) text, I am denying them their humanity. Rather than urging them to murder anything, I should be asking, "What do you think?" or "What do you mean?" and "Can you please tell me more?" I need to tap the curiosity that is the wellspring of writing - my own, as well as my students'.

At that earlier "killing my darlings" stage in my career, the internet was not yet the ubiquitous presence it is today, and so I did not Google the phrase. Had I been able to, I would have learned Eudora Welty and Steven King had also been credited with advising writers to murder any writing that blocks the doorway to the reader. I would have discovered journalist Forrest Wickman, who tracked the aphorism to "On the Art of Writing," a 1914 lecture by Arthur Quiller-Couch that counsels, "If you here require a practical rule of me, I will present you with this: 'Whenever you feel an impulse to perpetrate a piece of exceptionally fine writing, obey it-whole-heartedly —and delete it before sending my manuscript to press. Murder your darlings." But even if I had taken a steam-punk journey into the Web, I would not have changed my approach. At that point, I did not care who said "Kill your darlings"; I wanted only a bold affect. I would cling to that language of killing, to the unearned bliss of not questioning for too long.

I had never heard of Columbine. Or Blacksburg. Or Sandy Hook. In the 1980s they existed as towns and not as eternal markers of tragedy. My students were the children whose parents fretted about packing enough Granny apples with lunch. My students had never crouched in closets during active-shooter drills or walked through metal detectors, their backpacks weighted with bulletproof plates. Their elementary school teachers did not know how to weaponize a classroom, and their desks stood vulnerable only to being carved with Christopher loves Heather. I said to those college students, "Kill your darlings" because my best friend, a guidance counselor, didn't yet lie awake at night, wondering if she would ever have to choose between protecting students and leaving her own children without a mother. I had never sat through Run, Hide, Fight assemblies doubting my ability to do any of these things.

In the wake of these school killings, researchers began to consider the effects of trauma on students' ability to learn, but this research, too, was inflected by a blinding Whiteness that enacted its own version of killing its darlings. Adam Alvarez's examination of this research demonstrates that students of color experience more violent trauma than White students and that much of this violence is rooted in White supremacy. Unfortunately, much of the trauma research-in other words, how we understand the effect of trauma on students-fails to take into account racism's role in inflicting trauma. This failure is itself a form of racism that reproduces oppressive structures. The same can be said about writing instructors who invoke "kill your darlings," a metaphor linked to White supremacy through violence. Our students of color have been subjected to physical and spiritual violence at greater rates than our White students; a White professor like me who repeats a violent metaphor during the process of revision-which is itself already a brutal undertaking -is taking up the lash of White supremacy, regardless of intention.

In the 1980s, I did not think about the cocoon of my own Whiteness. I never experienced the daily, racialized violence that confronts my African American students, even when it does not burst through the door with a gun. It is the killing that assaults Black bodies every moment of every day, a racism Ta-Nehisi Coates describes as "a visceral experience, that ... dislodges brains, blocks airways, rips muscle, extracts organs, cracks bones, breaks teeth" (1). I learn, over time, that that violence forces itself into the conversations, The Talk, that African Americans have with their children, that I have had the unearned ease to forego.

I am learning to know. I think about Trayvon Martin and Tamir Rice and Eric Garner, and Breonna Taylor and George Floyd and Robert Fuller and all the other sons and daughters who have been murdered because of racism. I can no longer tell my students, "Kill your darlings." Who said it does not matter. How dared I repeat such a thing? I do not claim to have become an antiracist because I see that undertaking as a lifelong project that can never be finished. But I can no longer invoke metaphors connected to murder, regardless of their thrust, regardless of their pedigree, as I try to coax writers to the screen. Eliminate the dross, I say to myself and to them, but never run from finding out what you meant in the first place. We stand at our podiums. Words live, we say. Words matter, we say. Words pump blood and exhale breath. They can carry us. My students' words matter. So do mine.

When I started this essay, the January 6, 2021 attack on the Capitol, which resulted in murder, suicide, and national traumahad not yet occurred. Fomented by the language of violence, the attack was an expression of White supremacy, couched in all its wretched symbols, part of a long trajectory contorting language into a noose of hatred. It is inconceivable to me now more than ever that the language of violence has any place in the writing classroom.

As a writer, I move between shooing away the ego that clings to the ankles of my prose and remembering to ask what I wanted to 
say, even when I fear the answer. There's a difference between stubbornness - a refusal to relinquish that which holds me backand persistence, a nimble loyalty to what matters. As a teacher, I cringe at what I did not know, what I did and did not say, and strive to be open to all I have yet to learn. I want to revise my teaching. Most of all, I want to silence the privilege that prevents me from listening to the creators before me so that I ask about their darlings and hear the response.

\section{Works Cited}

Alvarez, Adam. "Seeing Race in the Research on Youth Trauma and Education: A Critical Review." Review of Educational Research, vol. 90, no. 5, June 2020, pp. 003465432093813, https://www.researchgate.net/ publication/342578094. Accessed 5 Feb. 2021.

Baker-Bell, April. Linguistic Justice: Black Language, Literacy, Identity, and Pedagogy. Routledge, 2020.

Baker-Bell, April, Tamara Butler and Lamar Johnson. "The Pain and the Wounds: A Call for Critical Race English Education in the Wake of Racial Violence." English Education, vol. 49, no. 2, Jan. 2017, pp. 116-129. https:// library.ncte.org/journals/ee/issues/v49-2/28917.

Coates, Ta-Nehisi. Between the World and Me. Text Publishing, 2015.

Inoue, Asao. Labor-Based Grading Contracts: Building Equity and Inclusion in the Writing Classroom. UP of Colorado, 2019.

Love, Bettina L. "An Essay for Teachers Who Understand Racism Is Real." Education Week, 12 June 2020, https:// www.edweek.org/leadership/opinion-an-essay-forteachers-who-understand-racism-is-real/2020/06.

Murray, Ira E., and Adam Alvarez. "Research to Practice: New Research on Helping Young Children Develop Positive Racial Identities." YC Young Children, vol. 71, no. 5, 2016, pp. 16-18. JSTOR, www.jstor.org/stable/ ycyoungchildren.71.5.16.

Wickman, Forrest. "Who Really Said 'I Should Kill My Darlings'?" Slate, 18 October 2013, https://slate.com/culture/2013/10/ kill-my-darlings-writing-advice-what-writer-really-said-tomurder-my-babies.html.

\section{Acknowledgements}

Lisa wishes to thank the readers and editors of Writers: Craft and Context for their generous reading and advice. 